\title{
Urban nutrient balance for Bangkok
}

\author{
Jens Færge ${ }^{\mathrm{a}, *}$, Jakob Magid ${ }^{\mathrm{a}}$, Frits W.T. Penning de Vries ${ }^{\mathrm{b}}$ \\ a Department of Soil Science and Plant Nutrition, Royal Veterinary and Agricultural University, Thorvaldsensvej 40, Frederiksberg, \\ 1871 Copenhagen, Denmark \\ ${ }^{\mathrm{b}}$ International Board for Soil Research and Management (IBSRAM), Phaholyothin Road, PO Box 9-109, Jatujak, \\ Bangkok 10900, Thailand
}

Received 17 May 2000; received in revised form 16 November 2000; accepted 19 December 2000

\begin{abstract}
To explore the options for recycling of nutrients from mega-cities to agricultural land, a nutrient balance model was developed. The balancing was done for Bangkok Province and considered nitrogen $(\mathrm{N})$ and phosphorus $(\mathrm{P})$. To estimate the food supply, the most decisive nutrient flow, an online database (FAOSTAT) was employed; its country level data are disaggregated to the urban level. A simple approach to estimate nutrient food flows is suggested.

The balance shows that only a small fraction of nutrients is recovered of the amount of $\mathrm{N}$ and $\mathrm{P}$ in the total food supply, currently about $7 \%$ and $10 \%$, respectively. On the other hand most (about $97 \%$ ), of the total loss of $\mathrm{N}$ can be accounted for by elevated $\mathrm{N}$ levels in the Chao Phraya river, and also much (about $41 \%$ ) of the $\mathrm{P}$ is lost through the river. So it appears that in- and outflow of $\mathrm{N}$ are almost in balance, but a large amount of $\mathrm{P}$ accumulates. The balance also shows that the organic waste from Bangkok Province discharged into the river (and the sea) contains huge quantities of plant nutrients that should be recovered and reused to close the ecological nutrient cycle. (C) 2001 Elsevier Science B.V. All rights reserved.
\end{abstract}

Keywords: Urban rural nutrient recycling; Nutrient balance modeling

\section{Introduction}

Our understanding of rural nutrient flows has improved greatly in the last few decades. ${ }^{1}$ It has been shown that some areas are exposed to intense nutrient mining and others to nutrient accu-

\footnotetext{
* Corresponding author. Tel.: + 45-3581-8643.

E-mail address: jf@dsr.kvl.dk (J. Færge).
}

\footnotetext{
${ }^{1}$ See Agric. Ecosyst. \& Environ. (71) 1998, Special Issue, dealing principally with nutrient balances.
}

mulation. But in contrast to the significant number of rural nutrient studies, we could find only one study (by Newcombe, 1977) that deals with urban nutrient flows. However, given the environmental problems resulting from mismanaged organic waste and expanding mega-cities, this lack of information must be addressed. Increased understanding of urban nutrient flows might also reveal the potentials for nutrient recycling to agriculture. Concomitantly, recycling can reverse nutrient mining as well as remediate health and environmental problems caused by the 
organic waste. The aim of this paper is to outline an urban nutrient balance model.

An urban nutrient balance model was developed for Bangkok Province, Thailand. Bangkok Province is home to Bangkok city, a very large city where issues of nutrient flows are expected to be very significant and for which many data are available. The Province is chosen rather then the city because statistical data are available at the provincial level. The balance was made for 1996, as more recent statistical data were not available. Initially, we aimed to include nitrogen $(\mathrm{N})$, phosphorus $(\mathrm{P})$, and potassium $(\mathrm{K})$ in the analyses. However, data for the major nutrient outflows from Bangkok only mention $\mathrm{N}$ and $\mathrm{P}$. Besides, environmental problems caused by insufficient waste management, for example eutrophication, are not related to $\mathrm{K}$. Therefore it was decided to focus only on $\mathrm{N}$ and $\mathrm{P}$.

This model is a simple inflow/outflow model, consisting of major flows of matter. A justification for such simple approach is a general uncertainty, or lack of knowledge, about many of the minor flows. Hence, the major effort in the modeling was estimating these flows. In the process of elaborating the model, at first our intention was to include the influence from environmental policies, fertilizer prices, human population etc. on the nutrient flows. In that way, the model could be employed to simulate the nutrient flows for different scenarios. However, given the limited availability of (secondary) data, we found this not yet possible. Therefore, contrasting most nutrient modeling studies presented in Ecological Modeling, the current model is a static model resembling typical agronomic nutrient balance studies.

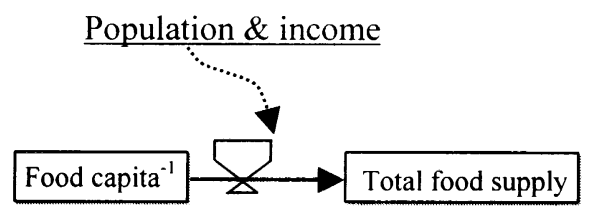

Fig. 1. Modeling total urban food supply: Population and income are driving variables, determining the total supply of food (imported and locally produced).

\section{Model description}

Before specifying the model, a brief description of Bangkok Province is appropriate. The population of Bangkok Province was 5.6 million in 1996 (NSO, 1997). Bangkok is located on a plain in the delta of the Chao Phraya river. Bangkok has a total area of $1565 \mathrm{~km}^{2}$ of which $21.6 \%\left(339 \mathrm{~km}^{2}\right)$ is used for farming. Most of the soil consist of dark gray clay, which is very suitable for paddy rice (Pendleton, 1942). Of the arable land in the Province, $73.6 \%$ is used for paddy rice, with smaller areas for fruit trees $(10.2 \%)$, vegetables $(4.6 \%)$, field crops $(0.6 \%)$ and other crops $(11.2 \%$; MOAC, 1998a).

\subsection{Nutrient flows}

The nutrient flows to and from Bangkok considered explicitly are those in food, fertilizer, animal feed, atmospheric deposition and waste water, as an a priori crude analysis indicated that these are by far the most important.

However, we could not locate data on food consumption as such. Data for average per capita food supply in Thailand can be found in the online database, FAOSTAT (FAO, 2000) and we used that to derive information on consumption in Bangkok. The total food supply to Bangkok, as will be discussed later, is calculated using the FAOSTAT database, population data for Bangkok and Thailand, and adjusted for higher average purchasing power in Bangkok than the rest of Thailand (Fig. 1). Some of the food purchased in Bangkok, though, is produced in Bangkok Province and does not cause any inflow of nutrients per se. The amount of nutrients in locally produced food has therefore been subtracted from the total amount of nutrients in food consumed in the city.

The inflow of nutrients to Bangkok is defined as the sum of nutrients in all food supplied for human consumption and nutrients in animal feed and fertilizer as well as atmospheric deposition of $\mathrm{N}$ minus nutrients in locally produced agricultural products. Fig. 2 shows the modeled inflow of nutrients. 


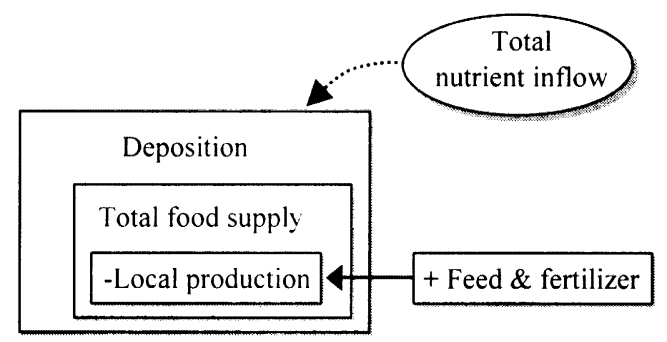

Fig. 2. The modeled inflow of nutrients to Bangkok is nutrients in the total food supply minus nutrients in locally produced food plus nutrients in feed, fertilizer and deposition of nitrogen.

For the balance, this definition implies that it does not matter whether agricultural products produced in Bangkok are consumed locally or exported, inasmuch as export of local products necessarily entails an increased import of externally produced food.

The outflow of nutrients from Bangkok is more difficult to estimate than the inflow. Food is either eaten or disposed of as food waste, resulting in the outflow of nutrients as either solid waste or sewage and nightsoil sludge. However not all of the outflow of nutrients will be found in solid waste and sludge. Nutrients are accumulated in the sediments of fishponds (Edwards, 1993) and probably also in the sediments of klongs (canals) and in the soil, as well as being discharged to aquatic and atmospheric environments.

To estimate the outflow of nutrients, data are available for solid waste collection, for sewage and nightsoil sludge and for the water quality of the Chao Phraya river. As there are no data for accumulation, it has to be estimated indirectly.

$\mathrm{N}$ can also be lost to the atmosphere by denitrification processes when organic matter decomposes with insufficient oxygen. Lacking basic data about the process, we were not able to quantify it.

To sum up, in the nutrient balance for Bangkok, the inflow includes the nutrients in the total supply of food, agricultural fertilizer and animal feed as well as atmospheric deposition of $\mathrm{N}$ minus nutrients in locally produced agricultural products. For outflow, the balance includes nutrients in collected waste and aquatic losses to the Chao Phraya river. Fig. 3 displays the modeled nutrient flows.

\section{Estimating nutrient flows and discussion}

\subsection{Nutrients in the total food supply to Bangkok}

From the online FAOSTAT database (FAO, 2000), we selected data on average per capita food supply in Thailand. The average income in Bangkok is higher than the average in Thailand (NSO, 1997) and conventional wisdom says that food consumption is income dependent (World Bank, 1986). To test whether this conventional wisdom is still valid, using data from 41 developing countries, Dawson (1997) analyzed the relation between calorie intake and income. The countries, in the analysis, have a range of income (GNP capita $^{-1} \mathrm{yr}^{-1}$ ) from US\$100 (Tanzania) to US\$2920 (Venezuela); energy intake (kcal capita $^{-1} \mathrm{yr}^{-1}$ ) from 1619 (Ethiopia) to 3330 (Tunisia) and a level of urbanization from $6 \%$ (Rwanda) to 91\% (Venezuela). The result of the analysis, using cross-sectional data from 1992, is an average income elasticity of 0.073 , ranging from 0.051 (Tunisia) to 0.111 (Ethiopia).

In general, when the economy grows, the income elasticity for food declines (Dawson and Tiffin, 1998). The average per capita GNP in Thailand in 1996 was US\$2750 (World Bank, 1999), and in the upper range of the above-mentioned analysis. We expect therefore that an income elasticity of 0.05 accounts for extra calorie demand in Bangkok compared to the average in Thailand. In other words: if the average income in Bangkok were twice the average in Thailand, the food demand would be 5\% higher. As the average per capita product in Bangkok is 3.4 times the average national product (NSO, 1997), we estimate the per capita food consumption in Bangkok to be $17 \%$ above the national average.

The adjustment of the total energy supply to income does not consider that diet composition is income dependent too (Rae, 1997; Jussaume, 1998; Rae, 1998). In general, the relative consumption of non-cereal products such as meat, fish, and vegetables is increasing as income grows. Substitution of cereals by meat will cause an increase in the $\mathrm{N}$ inflow. However, it is conceivable that an increased meat consumption can be 


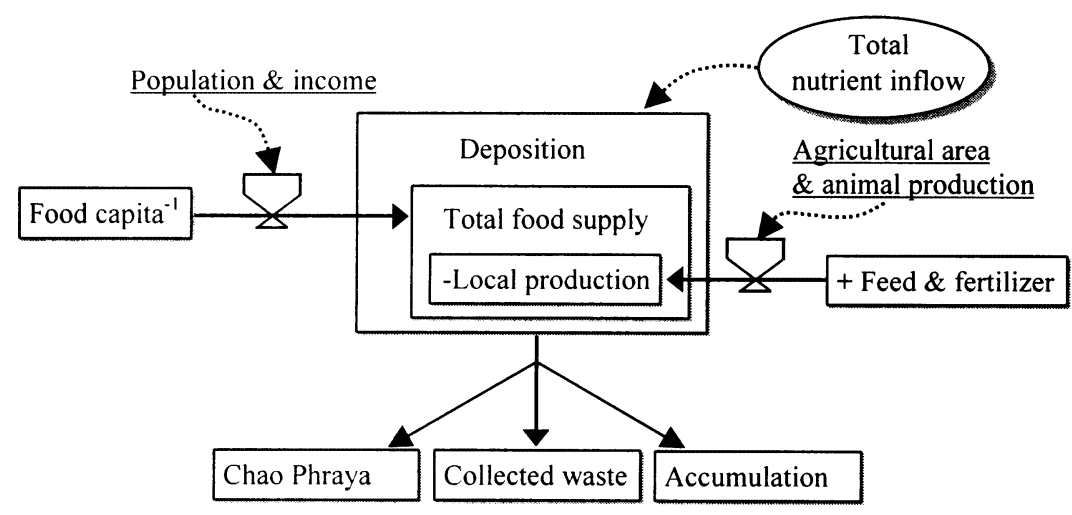

Fig. 3. Nutrients in food are modeled from data for supply capita ${ }^{-1}$ in Thailand, adjusted for income differences between Thailand and Bangkok. Nutrients in feed are modeled from the production of meat and use of fertilizer is calculated from the agricultural area. Nutrient outflow are nutrients in collected waste and nutrients discharged to Chao Phraya river. The accumulation of nutrients is calculated from the total inflow minus outflow of nutrients.

diluted, or equalized, by a concomitant increase in fat and/or vegetable consumption. Nevertheless, it is important to keep in mind that the present task is not to estimate the food flow of different food commodities per se. The task is simply to estimate the nutrients inherent in the food.

The increase in consumption of livestock products is small in Thailand compared to other East Asian countries (Simpson et al., 1994). For example, the consumption of meat in China rose from 13.6 to $23.1 \mathrm{~kg}$ capita $^{-1} \mathrm{yr}^{-1}$ from $1979-1981$ to 1989-1991, whereas the increase in Thailand only rose from 17.8 to 20.1. In addition, it can be argued (calculated from the FAOSTAT database) that the relative increase in total calorie and total protein supply in Thailand from 1965 to 1996 is almost similar.

In estimating the nutrient balance for Bangkok, it is assumed that this uniform trend over time in calorie and protein supply in Thailand is valid for present rural and urban diets. Consequently, for the balance, changes in diet do not have to be taken into consideration.

To summarize, the total supply of food to Bangkok, including locally produced food, is computed from the number of inhabitants and average national food supply data, augmented by $17 \%$ to account for the higher income in Bangkok than the average in Thailand.
The total food supply to Bangkok in 1996 is shown in Fig. 4. The amount of protein in the food is totally $121530 \mathrm{t}$, equivalent to $19445 \mathrm{t} \mathrm{N}$ (a conversion factor at $0.16^{2}$ between protein and $\mathrm{N})$. The content of $\mathrm{P}$ in beef, fish, eggs, milk, pork and poultry is calculated to be $1121 \mathrm{t}$ (calculated from Scherz and Senser (1994) and Beveridge (1987)). Fish constitutes $73 \%$ of all the seafood. To simplify, a common contents for $\mathrm{P}$ in fish is used for all the seafood.

The content of nutrients in vegetable products varies tremendously, depending heavily on soil fertility conditions (Marchner, 1995); this makes it difficult to chose valid values for all food eaten in Bangkok. We followed therefore a simple procedure, instead of looking for specific values for each different vegetable component: we link the $\mathrm{P}$ contents directly to that of $\mathrm{N}$. In most vegetable products, the $\mathrm{N} / \mathrm{P}$ ratios are quite stable due to fundamental biochemical relations. Walworth and Sumner (1987) give 16 ratios found in green leaf parts, collected from various literature sources. These ratios range from 8.2 to 15.3 . Soybean has

\footnotetext{
${ }^{2}$ For most types of protein the factor 0.16 is valid to convert from protein to $\mathrm{N}$, however, this procedure does not fit all types of protein (Chatfield, 2000). For example for rice protein, the factor is 0.17 . However, on account of the general level of uncertainty the factor 0.16 is used throughout the present balance. Chatfield (2000) presents factors (online) to convert protein in food items to $\mathrm{N}$.
} 
a much higher $\mathrm{N} / \mathrm{P}$ ratio than all other plant types. When soybean is excluded, the average $\mathrm{N} / \mathrm{P}$ ratio is equal to 10 . With this $\mathrm{N} / \mathrm{P}$ ratio and estimations for the content of protein in the food (FAOSTAT), one can estimate the total amount of $\mathrm{P}$ in plant products. However, because of the paramount importance of rice in the Thai diet, and hence for the nutrient balance, this standardization is not applied to rice. The $\mathrm{P}$ content in rice is estimated to be $0.185 \%$. In this way, the total flux of $\mathrm{P}$ into Bangkok in plant products is calcu-

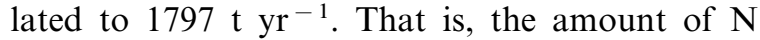
and $\mathrm{P}$ in the food supplied to Bangkok is esti-

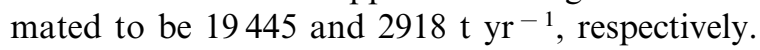

\subsection{Nutrients in the local production of food}

Food production in Bangkok is dominated by paddy rice, but also freshwater fish is important. Fig. 5 shows the total production in 1996/1997. The ratio of local production to total supply of freshwater fish, rice, vegetables, fruits, poultry, eggs and shrimps is $40 \%, 17 \%, 11 \%, 6 \%, 6 \%, 6 \%$ and $4 \%$, respectively, and less than $1 \%$ of beef and pork. The amount of $\mathrm{N}$ and $\mathrm{P}$ in the food is calculated as for the total food supply for Bangkok. The total amount of $\mathrm{N}$ and $\mathrm{P}$ in food produced in Bangkok is estimated to be 1995 and $306 \mathrm{t} \mathrm{yr}^{-1}$, respectively.

\subsection{Use of fertilizer}

Records of fertilizer use in Thailand are limited in number (PCD, 1997) and not separated by province (MOAC, 1998a) with the exception for paddy rice (MOAC, 1998b,c). From MOAC (1998b) and MOAC (1998c), it was derived that the average use of fertilizer ha ${ }^{-1}$ to paddy rice in Bangkok is 1.74 times larger than the average in Thailand.

To estimate the total use of fertilizer in Bangkok, it is assumed that the arable land not

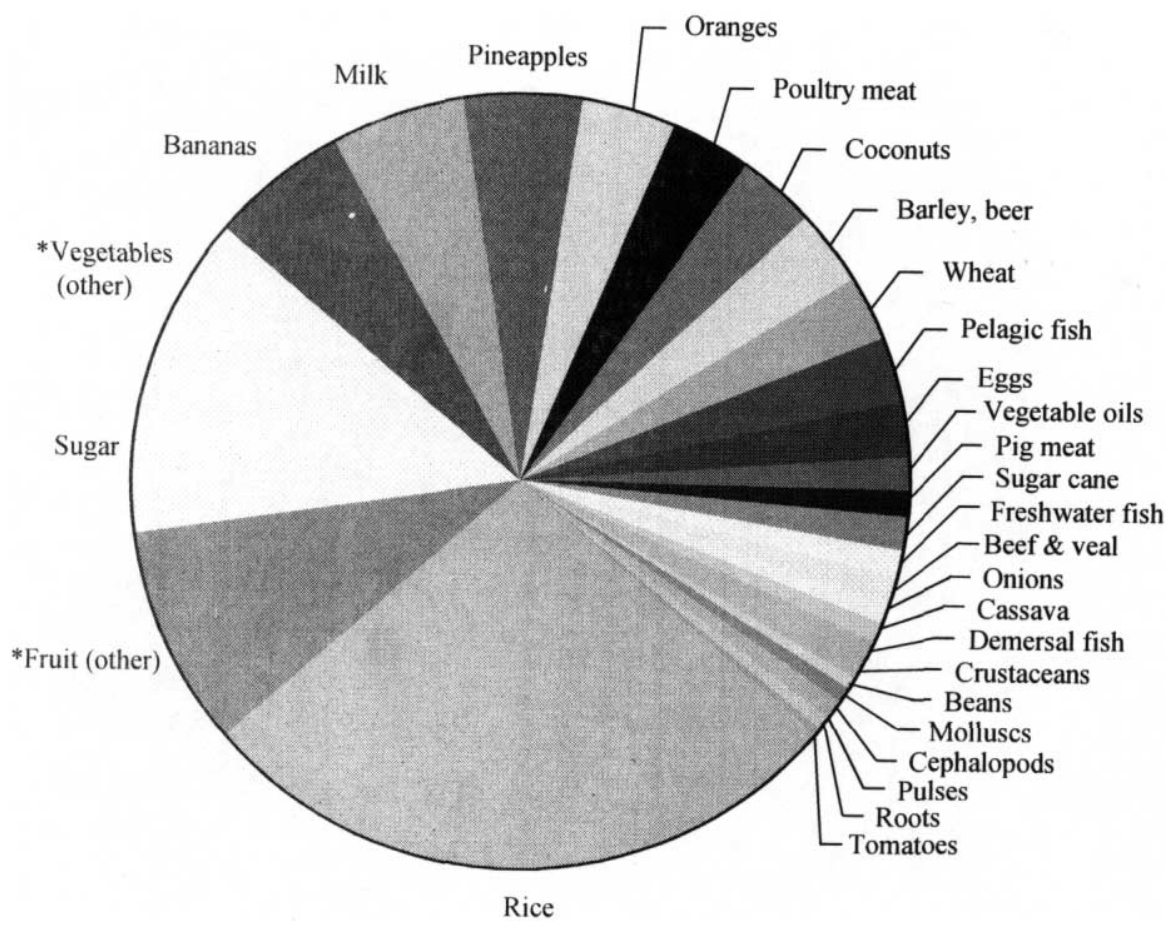

Fig. 4. Food supply to Bangkok in 1996. The total amount of food is $2689600 \mathrm{t}$, of which rice contributes $707400 \mathrm{t}$, fruit (other) $238600 \mathrm{t}$, sugar $193700 \mathrm{t}$, vegetables (other) $162100 \mathrm{t}$, bananas $150800 \mathrm{t}$, etc. The figure indicates $97 \%$ of the total food supply. (*) Vegetables (other) and fruits (other) are, vegetables and fruit not mentioned in the diagram. 


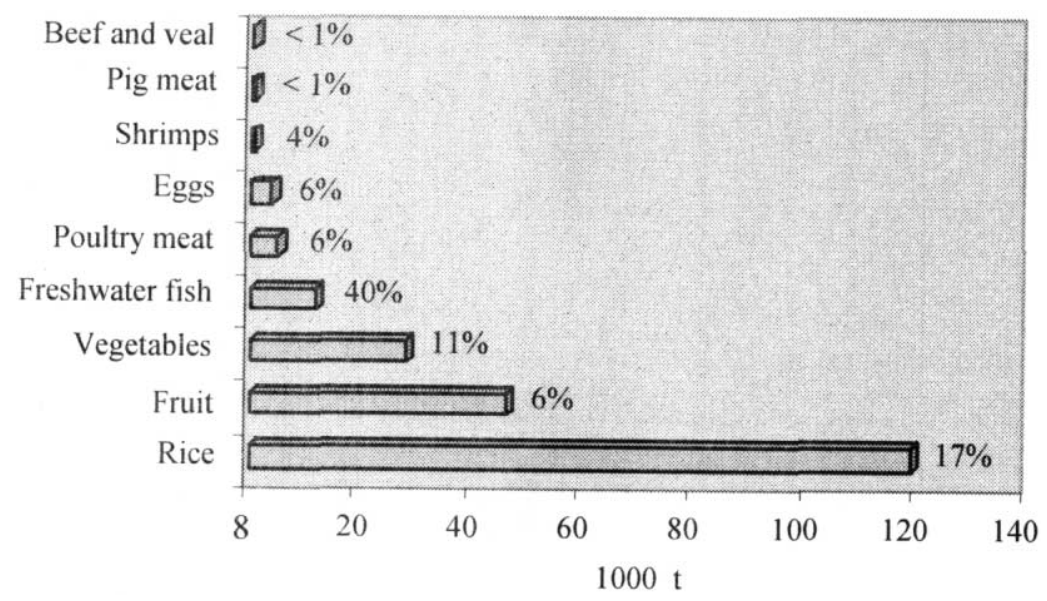

Fig. 5. Food production in Bangkok in 1996. The total amount of food is $226857 \mathrm{t}$, of which rice contributes $119304 \mathrm{t}$, fruit 45851 $\mathrm{t}$, vegetables $27752 \mathrm{t}$, etc. The percentages of the production in Bangkok, to the total food supply, is indicated. Data from MOAC (1998a,b,c, 1999) as well as not published data from MOAC.

used for paddy, is also given 1.74 times more fertilizer than the average amount to non-paddy arable land in Thailand. Under this assumption, the total use of industrial fertilizer in Bangkok in 1996 was estimated to be 2064 and $564 \mathrm{t}$ of $\mathrm{N}$ and $\mathrm{P}$, respectively (equivalent to an allocation of 61 and $17 \mathrm{~kg} \mathrm{ha}^{-1} \mathrm{yr}^{-1}$ of $\mathrm{N}$ and $\mathrm{P}$, respectively).

\subsection{Nutrients in feed for animal husbandry}

It was not possible to find statistical data about the actual amount of feed entering Bangkok. Consequently, the feed (or the inherent nutrients) entering Bangkok used in animal husbandry will, like the food supply, be estimated indirectly.

Freshwater fish culture is the most important animal product produced in Bangkok (Fig. 5) and subsequently for the balance, it is important to estimate accurately the use of fish feed. Fish can be reared at a very broad scale of intensification, varying from extensive to very intensive systems. If extensive, the pond, lake or rice field, used to rear the fish, in itself will produce all the feed. If the production is intensive, feed is allocated regularly and the pond may be considered similar to a feedlot. Semi-intensive systems, are fed with supplementary feed and/or fertilizers such as pig and poultry manure (Edwards, 1993). For the balance, intensive versus extensive production systems have opposite effects on the inflow of nutrients. For intensive systems there will be a surplus of nutrients, and for extensive systems, nutrients will be extracted from the system.

To estimate the feed or nutrient input to produce fish in Bangkok it is therefore necessary to know whether the production is extensive, intensive or somewhere in between. Currently in Bangkok, fish are reared mainly in semi-intensive ponds fed with pelleted and homemade feed, food waste as well as pig and chicken manure. For many farmers the feeding procedure is dependent on the availability of waste or scrap fish; a feeding procedure which makes it extremely difficult to estimate the average use of feed as well as feed conversion ratios. Where pelleted feed is used intensively, the feed conversion ratio is about 1.5-2 (Boonyaratpalin, 1999).

Nutrient conversion ratios for $\mathrm{N}$ and $\mathrm{P}$ calculated for intensive fish production are highly dependent on the conversion ratio between fish feed and produced fish. For a feed conversion ratio of 1.75 , the nutrient conversion ratio for $\mathrm{N}$ and $\mathrm{P}$ from fish feed to produced fish is in the order of 3.3 and 6.2, respectively (Edwards, 1993).

If freshwater fish and shrimp production in Bangkok is aggregated and the average feed conversion ratio is 1.75 , the $\mathrm{N}$ and $\mathrm{P}$ inflow in feed for aquaculture are 1031 and $257 \mathrm{t} \mathrm{yr}^{-1}$, respec- 
tively. However, this is the inflow if the production were intensive and solely fed with industrial feed. Therefore, the 'true' inflow must be somewhat lower. Nevertheless, failing to estimate how much, this maximum estimate will be used in the balance.

If the nutrient conversion ratio for $\mathrm{N}$ and $\mathrm{P}$ in the rest of the animal produce equal 5 and 10, the estimated inflow of $\mathrm{N}$ and $\mathrm{P}$ is 1207 and $186 \mathrm{t}$ $\mathrm{yr}^{-1}$, respectively.

To sum up, we estimate the $\mathrm{N}$ and $\mathrm{P}$ in the feed used in Bangkok in total to be 2238 and $443 \mathrm{t}$ $\mathrm{yr}^{-1}$, respectively.

\subsection{Nutrients in atmospheric deposition}

The deposition of $\mathrm{P}$ from the atmosphere is ignored in the balance as its value is low (often estimated to a few $\mathrm{g} \mathrm{ha}^{-1}$ ) compared to inflow of $\mathrm{P}$ in food, feed and fertilizer. But atmospheric $\mathrm{N}$ deposition, mainly due to fossil fuel combustion and agricultural production has to be considered.

It was not possible to find an estimate for $\mathrm{N}$ deposition in Bangkok. However the deposition in large parts of Europe is estimated to be around 30 $\mathrm{kg} \mathrm{N} \mathrm{ha}{ }^{-1} \mathrm{yr}^{-1}$ and the deposition in several parts of Asia is alike the deposition found in Europe (Galloway, 1998). We estimated for Bangkok Province the same level of $\mathrm{N}$ deposition, corresponding to a total deposition in Bangkok Province of $4695 \mathrm{t} \mathrm{N} \mathrm{yr}^{-1}$.

\subsection{Nutrients in waste}

Wastewater and nightsoil collection and treatment covered in 1996 on average about 2\% and

Table 1

Amount of food waste, nightsoil and sewage sludge collected in Bangkok (1996) and amount of $\mathrm{N}$ and $\mathrm{P}$ in the waste ${ }^{\mathrm{a}}$

\begin{tabular}{llrr}
\hline Waste type (t) & Amount & N & P \\
\hline Nightsoil sludge & $* 10300$ & 283 & 103 \\
Sewage sludge & 2086 & 20 & 6 \\
Food waste & 620000 & 1120 & 168 \\
Total waste & $\#$ & 1423 & 277 \\
\hline
\end{tabular}

\footnotetext{
a Calculated with data from AIT (1995), DPC (1997) and Stoll and Parameswaran (1996)
}

$19 \%$, respectively of the quantities generated in Bangkok (DPC, 1997; Stoll and Parameswaran, 1996). The amount of food waste, sewage and nightsoil sludge and the estimated nutrients therein can be seen in Table 1. We could not find data for the nutrient content in the food waste. Since waste is generally of lower nutritional quality than food, its $\mathrm{N}$ and $\mathrm{P}$ contents is approximated as $25 \%$ of that in food. The total amounts of $\mathrm{N}$ and $\mathrm{P}$ in collected waste were calculated to

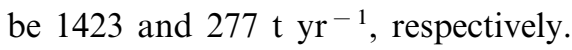

\subsection{Nutrients discharged to the aquatic environment}

The Pollution Control Department in Thailand (PCD, 1997) has measured the water quality at 32 stations along the Chao Phraya river since 1988. The content of $\mathrm{N}$ and $\mathrm{P}$ in water samples near the river mouth is about 1.3 and $0.08 \mathrm{mg}^{-1}$ above the content in the water station at Nonthaburi near the upstream border of Bangkok. The average annual outflow of water from the Chao Phraya river is about $590 \mathrm{~m}^{3} \mathrm{~s}^{-1}$. Ignoring eventual denitrification as well as $\mathrm{P}$-sorption processes, we estimate the load of $\mathrm{N}$ and $\mathrm{P}$ from Bangkok to the Chao Phraya river to be 24206 and $1490 \mathrm{t}$ $\mathrm{yr}^{-1}$, respectively.

\subsection{Uncertainty of nutrient flows}

Most of the estimations, constituting the present nutrient balance, are heavily dependent on literature-based values (e.g. nutrient content in food, feed conversion ratios etc.). However, browsing the literature, it is possible to find a wealth of different values, resulting in highly varying estimations, when extrapolated to all the food and feed flowing to Bangkok. A discussion about certainty is therefore appropriate.

For the accuracy of our calculations, the most important set of data for our calculations is that about the nutrient inflow, based on the FAOSTAT food supply data (FAO, 2000). We are not in a position to discuss the reliability of this database, but it is clear that eventual biases in FAOSTAT would be reflected directly in the nutrient balance. 
An important issue is the nutrient content in the food and particularly in rice, which, as can be seen from Fig. 4 is clearly the most important food component in the diet in Thailand. (On average, rice constitutes $47 \%$ of the total calorie intake.) Estimations of nutrient content in rice are therefore crucial for the total nutrient balance.

The rest of the nutrient inflows are of minor impact for the total balance. If for instance, factor 3 instead of factor 1.74 were used for fertilizer use to non-paddy land, it would only increase the estimate for use of fertilizer by $15 \%$ or 316 and 84

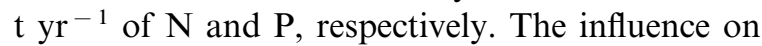
the total $\mathrm{N}$ and $\mathrm{P}$ inflow would thereby only increase by about $1 \%$ and $2 \%$.

The nutrient outflow, mainly consisting of collected waste and discharge to the Chao Phraya river, is based respectively on statistical information and continued measurements for several years of $\mathrm{N}$ and $\mathrm{P}$ contents in the water of Chao Phraya river. It is rather straightforward to estimate the amount of solid waste and sludge and the data are therefore considered reliable. Further the nutrient contents measured in the waste are consistent with default values from Tchobanoglous (1991). The estimation of $\mathrm{N}$ and $\mathrm{P}$ in the Chao Phraya river are also straightforward, and inasmuch as the estimate is an average for several years, the estimates are considered reliable too.

It has not been possible to find a reliable national average value for nutrient content in rice in Thailand. It is therefore necessary to estimate the nutrient content in the rice consumed in Bangkok.

Estimations of nutrients in rice, based on observations from 50-100 experiments, show $\mathrm{N}$ and $\mathrm{P}$ content varying from $0.97-1.36$ and $0.1-0.27 \%$, respectively, where minima and maxima refer to $12.5 \%$ and $87.5 \%$ quantiles, respectively (Van Duivenbooden et al., 1996). Inasmuch as the variability in $\mathrm{P}$ content is much higher than the variability of $\mathrm{N}$ content the following discussion only deals with $\mathrm{P}$.

As noted earlier, the content of nutrients in grain is highly correlated to the fertility regime under which the crop is grown. The $\mathrm{P}$ content in the rice consumed in Bangkok might therefore be judged from the inherent fertility of soils in Thai- land and the use of fertilizers. The soils in Thailand are in general not fertile (Pramojanee and Sato, 1991). However, data from FAOSTAT shows that the total use of chemical fertilizers has increased substantially in the last 10-20 yr (FAO, 2000). For example, employing a medium value for P content (Van Duivenbooden et al., 1996) and average national crop data for paddy rice in Thailand (MOAC, 1998a), and assuming that only the grain is harvested, shows a surplus in 1996 of $4 \mathrm{~kg} \mathrm{P} \mathrm{ha}^{-1}$. Given the correlation between fertility and nutrient content, the former low fertility of the soils and the present surplus of $\mathrm{P}$, it is judged that the rice consumed in Bangkok could have a medium content of $\mathrm{P}$; that is, in between the minima and maxima values from Van Duivenbooden et al. (1996). Consequently, the value used to calculate the total amount of $P$ in rice is $0.185 \%$.

It could be argued that not only rice, but probably also other vegetables, must benefit from the increase in fertilizer use, for which reason the nutrient content should be adjusted in these vegetables also. However, rice is the main stable food component in Thailand and, as noted above, the most bulky food component in the Thai diet. In addition, the above discussion about $\mathrm{P}$ content is not only to estimate the nutrient content in rice but also to indicate the importance of selecting adequate (default) values when browsing the literature. It is indeed possible to find default values for $\mathrm{P}$ content in rice at the minima (FAO, 1982) as well as higher than the maxima (Gebhardt and Matthews, 1991) values indicated by Van Duivenbooden et al. (1996). Or in other words, using default values, the estimated $\mathrm{P}$ content in the $707400 \mathrm{t}$ of rice supplied to Bangkok annually can differ more than the (considerable) load of $\mathrm{P}$ from Bangkok to the Chao Phraya river.

\subsection{Nutrient balance for Bangkok Province}

The inflow of nutrients, in the present nutrient balance for Bangkok, is defined as nutrients in the total supply of food, agricultural fertilizer and animal feed as well as atmospheric deposition of $\mathrm{N}$ minus nutrients in locally produced agricultural products. The outflow is defined as nutrients in 


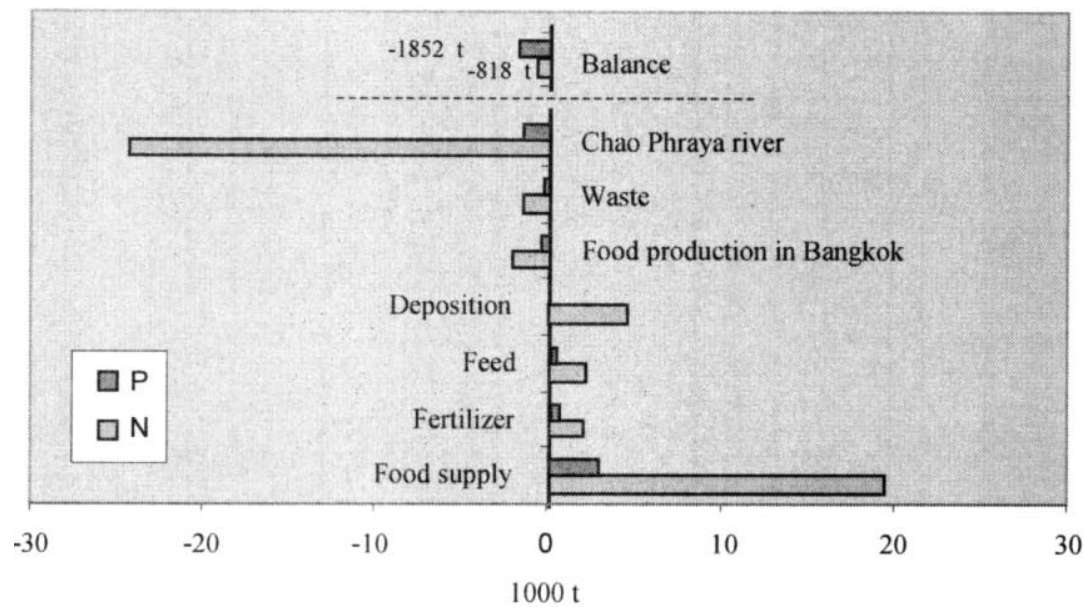

Fig. 6. Nutrient balance for Bangkok, 1996. The inflow of nutrients is indicated on the right side of the figure and the outflow on the left. Subtracting outflow from inflow shows an inflow of $\mathrm{N}$ and $\mathrm{P}$ of, respectively, 818 and $1852 \mathrm{t} \mathrm{yr}^{-1}$ in excess of outflow.

collected waste and aquatic losses to the Chao Phraya river.

Compilation of the estimations for in- and outflows show an inflow of $\mathrm{N}$ and $\mathrm{P}$ of 818 and $1852 \mathrm{t}^{-1}$, respectively, in excess of outflow (Fig. 6). Or, in other words, the outflow of $\mathrm{N}$ and $\mathrm{P}$ is found to be, respectively, $97 \%$ and $49 \%$ of the inflow. In relation to the general uncertainty of the nutrient flows estimated it is quite surprising that the calculations for $\mathrm{N}$ almost balance!

The Chao Phraya river is obviously a very important recipient for nutrients. Of the total inflow of $\mathrm{N}$ and $\mathrm{P}, 92 \%$ and $41 \%$ is discharged to the river and only $5 \%$ and $8 \%$, respectively, is collected in waste. Yet half $(51 \%)$ of the inflow of $\mathrm{P}$ is not accounted for and must accumulate elsewhere. Some must accumulate in agricultural soils. If eventual use of animal manure is ignored, it can be calculated that the crops grown in Bangkok only remove about half of the $\mathrm{P}$ applied in fertilizer. The accumulation of $\mathrm{P}$ at the minimum therefore, must be $250-300 \mathrm{t}^{-1}$ or at least $8 \mathrm{~kg} \mathrm{ha}^{-1} \mathrm{yr}^{-1}$. This agricultural accumulation however, only accounts for a minor part of the $\mathrm{P}$ not found. But for the time being, to say where and how this $\mathrm{P}$ accumulates is guesswork. Of cause, one explanation could be that the inflow of $\mathrm{P}$ is overestimated. Another plausible explanation is that most of the $\mathrm{P}$, besides a minor accu- mulation in agricultural soils, is accumulated in the klongs (canals), fishponds and wherever organic waste is in contact with soil, since $\mathrm{P}$ has a high affinity for sorption in most soil constituents (Frossard et al., 1995).

\subsection{Actual and potential nutrient recovery}

Wastewater and nightsoil collection and treatment covered, respectively, $2 \%$ and $19 \%$ of the generation in Bangkok in 1996. According to a Masterplan for Bangkok (AIT, 1995), it is intended to establish 10 central wastewater treatment plants and four nightsoil treatment plants, after which about $42 \%$ and $50 \%$, respectively, of the wastewater and nightsoil generation should be treated. The expected amounts of sewage and nightsoil sludge from these plants are respectively 36500 and $25550 \mathrm{t} \mathrm{yr}^{-1}$ of dry matter (Eckhardt and Khatiwada, 1998). From the expected amounts of waste it is possible to calculate the potential nutrient recovery fraction (NRF), defined as the ratio of nutrients recovered in waste of the nutrients in the total food supply.

Table 2 shows the current NRF, its value if the Masterplan for sewerage were implemented, and its value if the sewerage system covered all households in Bangkok. The table also shows the expected application of $\mathrm{N}$ and $\mathrm{P}$ if the waste were 
recycled to the agricultural soils in the Bangkok Province.

The current NRF is only $7 \%$ and $10 \%$, corresponding to an average allocation of 42 and $8 \mathrm{~kg}$ $\mathrm{ha}^{-1} \mathrm{yr}^{-1}$ of $\mathrm{N}$ and $\mathrm{P}$, respectively. After implementation of the Masterplan, the NRF would be $11 \%$ and $18 \%$, which, if fully recycled, correspond to 64 and $16 \mathrm{~kg} \mathrm{~N}$ and $\mathrm{P}$ ha ${ }^{-1} \mathrm{yr}^{-1}$. If the sewerage system would cover all households (i.e. more than the $42-50 \%$ as intended in the Masterplan), NRF would be $17 \%$ and $33 \%$, and the corresponding potential for recycling would be 99 and $28 \mathrm{~kg} \mathrm{~N}$ and $\mathrm{P} \mathrm{ha}^{-1} \mathrm{yr}^{-1}$.

That is, the calculated recovery fraction of nutrients from the inflow in the situation that all households are connected to the sewerage system, would be 0.17 and 0.33 of $\mathrm{N}$ and $\mathrm{P}$, respectively. This recovery fraction is still low and indicates that most of the plant nutrients will be lost even after the enlargement of the sewerage system.

\section{Outlook}

This paper has focused on actual nutrient flows in and around Bangkok. The total food supply to Bangkok, the single most important nutrient flow, is mainly calculated with data from the FAOSTAT database and the population of Bangkok. To validate this procedure, actual measurements of food flows have to be carried out for a number of cities.

However, we do not advocate to wait for such a validation before attempting construction of nutrient balances for other cities, as the crucial recycling problems cannot await full scientific understanding. We suggest to estimate the amount of $\mathrm{N}$ and $\mathrm{P}$ in food consumed in a certain urban area by following the crude approach of estimating the amount of vegetable and animal protein consumed per capita, adjusted for rural/urban economic inequalities and multiplied by the population of the area. The total amount of $\mathrm{N}$ and $\mathrm{P}$ can then be calculated by assuming a $\mathrm{N} / \mathrm{P}$ ratio of 5 and 10 for animal and vegetable protein, respectively.

To enhance agricultural sustainability, the former urban rural linkages must be reintroduced (Liebig, 1846; Howard, 1940; UNDP, 1996; Magdorf et al., 1997). However, extrapolation of the waste flows expected in the Masterplan to apply for all households in Bangkok, reveals that most of the plant nutrients entering Bangkok will still be lost. For future research it is therefore of particular interest to explore the potential recycling of nutrients, for which the maximum recovery fraction in different waste management systems must be examined.

In closing, a remark about sustainability. Obviously, recycling from cities of nutrients of agricultural origin must enhance agricultural sustainability per se. But, how far such recycling also increases the sustainability of our society is more elusive. That is, in some cases, the environmental technology for disposing waste creates more waste than it removes (Odum, 1982). However, photosynthesis in oceans is mostly nutrient limited (mainly by P), and waste-P transported to the ocean contributes to global photosynthesis. If it were possible to harvest food from this process, then, in an even broader perspective, it is uncertain whether recycling nutrients to rural and periurban areas is preferable over transport to nutrient poor oceans from the point of view of long-term sustainability.

Table 2

NRF currently and if a Masterplan for sewerage (AIT, 1995) was implemented and extrapolated to all households in Bangkok ${ }^{\text {a }}$

\begin{tabular}{|c|c|c|c|c|}
\hline & $\mathrm{N}$ recovery $(\%)$ & $\mathrm{P}$ recovery $(\%)$ & $\mathrm{kg} \mathrm{N} \mathrm{ha}{ }^{-1} \mathrm{yr}^{-1}$ & $\mathrm{~kg} \mathrm{P} \mathrm{ha} \mathrm{yr}^{-1}$ \\
\hline Current situation & 7 & 10 & 42 & 8 \\
\hline Masterplan & 11 & 18 & 64 & 16 \\
\hline All households & 17 & 33 & 99 & 28 \\
\hline
\end{tabular}

\footnotetext{
${ }^{\text {a }}$ In addition amount per hectare of $\mathrm{N}$ and $\mathrm{P}$ if the waste was recycled to Bangkok soils. NRF is calculated as the ratio of nutrients in waste of the amount of nutrients in the total food supply
} 


\section{Acknowledgements}

The authors want to thank all individuals who provided information for this paper. Especially we want to thank Pinsiri Nonthakarn and Suraphol Chandrapatya from IBSRAM for their invaluable help.

\section{References}

AIT, 1995. Masterplan on treatment and disposal of domestic sewage including nightsoil and oil and grease residues for Bangkok Metropolitan. Bangkok Metropolitan Administration - Asian Institute of Technology, Bangkok.

Beveridge, M.C.M., 1987. Cage Aquaculture. Farnham, Fishing News, 352 pp.

Boonyaratpalin, M., 1999 (personal information). National Inland Freshwater Institute, Bangkok.

Chatfield, C., 2000. Food composition tables for international use (Electronic document only). FAO, Rome. Internet access: http://www.fao.org/docrep/x5557e/ x5557e00.htm \# Contents.

Dawson, P.J., 1997. The demand for calories in developing countries. Oxford Develop. Stud. 25 (3), 361-369.

Dawson, P.J., Tiffin, R., 1998. Estimating the demand for calories in India. Am. J. Agr. Econ. 80 (3), 474-481.

DPC, 1997. Department Public Cleansing. Bangkok Metropolitan Administration, Bangkok. 172 pp. (in Thai).

Eckhardt, H., Khatiwada, N.R., 1998. Feasibility Study of Agricultural Application of Sewage and Nightsoil Sludges from Bangkok Metropolitan. In: Proceedings of the Water Environ. Fed. Tech. Conference. Exhibition Asia, Singapore, vol. 2, 665 pp.

Edwards, P., 1993. Environmental issues in integrated agriculture-aquaculture and wastewater-fed fish culture systems. In: Pullin, R.S.V., Rosenthal, H., Maclean, J.L. (Eds.), Environment and Aquaculture in Developing Countries, pp. 139-170. ICLARM Conference, Proceedings, vol. 31, $351 \mathrm{pp}$.

FAO, 1982. Food Composition Table for the Near East. FAO, Rome. 265 pp.

FAO, 2000. FAOSTAT Database. FAO, Rome. Internet access: http://apps.fao.org/default.htm.

Frossard, E., Brossard, M., Hedley, J.M., Metherell, A., 1995. Reactions controlling the cycling of $\mathrm{P}$ in soils. In: Thiessen, H. (Ed.), Phosphorus in the Global Environment Transfers, Cycles, and Management. John Wiley Chichester, New York. 464 pp.

Galloway, J.N., 1998. The global nitrogen cycle: changes and consequences. Environ. Pollut. 102 (Suppl. 1), 15-24.

Gebhardt, S.E., Matthews, R.H., 1991. Nutritive value of foods. Home and Garden Bulletin no. 72, Department of Agriculture, Washington DC, $72 \mathrm{pp}$.
Howard, A., 1940. An Agricultural Testament. Oxford University Press, Amen House, London, p. 255.

Jussaume, R.A. Jr., 1998. Variations in food consumption patterns in urban China. Sociological Abstracts 046.

Liebig, J., 1846. Chemische Briefe. Akademissche Verlagshandlung von G.F. Winter. Heidelberg, 342 pp.

Magdorf, F., Lanyon, L., Liebhardt, B., 1997. Nutrient cycling, transportation, and flows: implications for a more sustainable agriculture. Adv. Agron. 60, 1-73.

Marchner, H., 1995. Mineral Nutrition of Higher Plants, second ed. Academic Press, London, p. 889.

MOAC, 1998a. Agricultural Statistics of Thailand Crop Year 1996/97. Ministry of Agriculture \& Co-operatives, Bangkok. 307 pp.

MOAC, 1998b. Report of First Rice, Crop Year 1996/97. Ministry of Agriculture \& Co-operatives, Bangkok.

MOAC, 1998c. Report of Second Rice, Crop Year 1996/97. Ministry of Agriculture \& Co-operatives, Bangkok.

MOAC, 1999. Freshwater Fish farm Production 1996. Ministry of Agriculture \& Co-operatives, Bangkok.

Newcombe, K., 1977. Nutrient flow in a major urban settlement: Hong Kong. Hum. Ecol. 5 (3), 179-208.

NSO, 1997. Statistical Year Book nr. 44. National Statistical Office, Bangkok. 412 pp.

Odum, H.T., 1982. Systems Ecology: An Introduction. Wiley, New York, p. 644.

PCD, 1997. Development of an action plan to improve water quality in the central river basin, Thailand. Annex: Water Quality Modelling. Pollution Control Department, Ministry of Science, Technology and Environment, Bangkok.

Pendleton, R.L., 1942. A preliminary report on the soils and agriculture of the lower central of Bangkok area of Thailand. Department of Agriculture, Bangkok. 160 pp.

Pramojanee, P., Sato, Y., 1991. Soils, site selection and characterization. In: Yoshida, T., Yamazaki, K., Nakano, M., Fukami, M., Ushikubo, A., Sato, Y. (Eds.), Dynamics and Its Control of Soils in Tropical Monsoon Regions, Report of Survey and Research in Thailand. Ministry of Education, Science and Culture, Japan.

Rae, A.N., 1997. Changing food consumption patterns in East Asia: implications of the trend towards livestock products. Agribusiness: Int. J. 13 (1), 33-44.

Rae, A.N., 1998. The effect of expenditure growth and urbanization on food consumption in East Asia: a note on animal production. Agri. Eco.: J. Int. Assoc. Agri. Econ. 18 (3), 291-299.

Scherz, H., Senser, F., 1994. Food Composition and Nutrition Table, fifth ed. CRC Press, Stuttgart. 1091 pp.

Simpson, J.R., Cheng, X., Miyazaki, A., 1994. China's Livestock and Related Agriculture Projections to 2025. CAB International, Wallingford, p. 474.

Stoll, U., Parameswaran, K., 1996. Treatment and disposal of domestic sewage sludge and nightsoil sludge for Bangkok. Water Sci. Technol. 34 (11), 209-217.

Tchobanoglous, G., 1991. Wastewater Engineering: Treatment, Disposal, and Reuse. McGraw Hill, Maidenherd, NY, p. 1334. 
UNDP, 1996. Urban Agriculture, Food, Jobs and Sustainable Cities. United Nations Development Program, New York. 299 pp.

Van Duivenbooden, N., De Wit, C.T., Van Keulen, H., 1996. Nitrogen, phosphorous and potassium relations in five major cereals reviewed in respect to fertilizer recommendations using simulation modelling. Fert. Res. 44, 37-49.

Walworth, J.L., Sumner, M.E., 1987. The diagnosis and rec- ommendation integrated system. Adv. Soil. Sci. 6, 149188.

World Bank, 1986. Poverty and Hunger - Issues and Options for Food Security in Developing Countries. The World Bank, Washington DC. 69 pp.

World Bank, 1999. World development indicators. The World Bank, Washington DC. 400 pp. Internet access: http:// www.worldbank.org/data/countrydata/littledata/211.pdf. 